\title{
Tindakan Hukum atas Pelanggaran Hak Cipta pada Digitalisasi Ciptaan melalui Media Over the Top
}

\author{
Abel Nicholas L. Tobing, Rika Ratna Permata, Tasya Safiranita Ramli \\ Fakultas Hukum, Universitas Padjadjaran, Bandung, Indonesia \\ Email: abelnicholastobing@gmail.com; permata_rika@yahoo.com; \\ tasya_safiranita@yahoo.com
}

\begin{abstract}
ABSTRAK
Perkembangan teknologi yang ada saat ini telah menghadirkan suatu kemudahan bagi masyarakat dalam mengakses sesuatu di internet, terlebih lagi telah hadir Media Over the Top yang memberikan kemudahan dalam memberikan layanan aplikasi maupun penyediaan konten. Kehadiran Media Over the Top tersebut juga digunakan oleh pencipta saat ini dalam mendistribusikan hasil ciptaannya di internet melalui Media Over the Top yang mana hal ini dikenal sebagai digitalisasi ciptaan. Namun hal ini juga menghadirkan kemudahan bagi beberapa pihak dalam melakukan pelanggaran hak cipta terhadap digitalisasi ciptaan tersebut. Maka, penelitian ini dimaksudkan guna memahami pelindungan hukum bagi pencipta terhadap digitalisasi ciptaan di Media Over the Top serta guna mengetahui tindakan hukum yang tepat bagi pencipta atas pelanggaran hak cipta di Media Over the Top. Pada penelitian ini, penulis menggunakan metode penelitian normatif melalui penelitian terhadap bahan pustaka serta dengan data sekunder melalui pendekatan yuridis normatif yang bersifat deskriptif analitis, sehingga pada penelitian ini akan ditinjau dan dianalisis regulasi yang berkaitan dengan pokok permasalahan. Terhadap hasil penelitian ini telah jelas menunjukkan bahwa sejatinya UndangUndang Republik Indonesia Nomor 28 Tahun 2014 belum mengatur secara komperhensif terhadap digitalisasi ciptaan di Media Over the Top yang berbasis sistem elektronik. Sehingga, pencipta perlu untuk melakukan tindakan hukum berupa gugatan ganti rugi di pengadilan niaga atau mengajukan laporan pidana serta membuat laporan penutupan konten dan/atau hak akses ke Direktorat Jenderal Kekayaan Intelektual jika terdapatnya pelanggaran hak cipta pada digitalisasi ciptaan melalui Media Over the Top.
\end{abstract}

Kata Kunci: Hak Cipta, Digitalisasi Ciptaan, Media Over the Top, Pelanggaran Hak Cipta, Tindakan Hukum.

\section{PENDAHULUAN}

Globalisasi telah memberikan suatu dampak kemajuan teknologi kepada manusia dalam melakukan kegiatan kesahariannya dalam setiap aspek kehidupan (Tasya Ramli, 2019, p. 2). Melalui globalisasi tersebutlah, dunia teknologi terus berkembang di masyarakat dan telah membuat suatu perubahan-perubahan bagi setiap manusia untuk dapat melakukan kegiatan kesehariannya dengan tidak mengenal batas wilayah negara atau yang biasa dikenal dengan istilah borderless (Ahmad Ramli, 2006, p. 1).

Perkembangan yang terus terjadi dewasa ini, tentunya telah membuat hukum juga telah mengarahkan perkembangan tersebut ke arah industri teknologi yang dikenal dengan istilah konvergensi media (M. Fikri, 2018, p. 32). Maksud dari perkembangan yang mengarah kepada konvergensi media merupakan suatu perkembangan yang terdapatnya penggabungan antara media radio, televisi, surat kabar, maupun internet, sehingga terbentuklah suatu media tunggal (Joseph D., 2012, p. 5). Atas perkembangan tersebut jugalah hukum ikut berkembang untuk 
memberikan suatu upaya penanggulangan agar tidak terjadinya kejahatan dengan dibentuknya cyber law sebagai bentuk benteng pertahanan (Darmawan, 2017, p. 102)

Perwujudan nyata dari konvergensi media adalah dengan hadirnya Media Over the Top. Media Over the Top sendiri merupakan suatu layanan (services) pada dunia digital atau internet dengan menggunakan manfaat dari koneksi internet maupun infrastruktur internet yang disediakan oleh Telco World (suatu wilayah bagi para penyedia layanan komunikasi serta jaringan komputer atau internet berada).

Perwujudan nyata dari konvergensi media adalah dengan hadirnya Media Over the Top. Media Over the Top sendiri merupakan suatu layanan (services) pada dunia digital atau internet dengan menggunakan manfaat dari suatu hubungan ataupun prasarana internet yang disajikan oleh Telco World. Telco World sendiri merupakan wilayah bagi pemberi jasa komunikasi dan jaringan komputer melalui internet.

Kehadiran Media Over the Top pada masyarakat tentunya diharapkan dapat memberikan suatu gaya hidup baru pada masyarakat untuk mengakses suatu konten yang dilindungi kekayaan intelektual terkhususnya hak cipta secara sah dan tidak melanggar hak orang lain. Sehingga, kehadiran Media Over the Top tersebut diharapkan dapat mengurangi angka akses tidak sah terhadap suatu ciptaan maupun pelanggaran hak cipta (Borja, 2016, p. 86-96).

Namun sungguh disayangkan, kehadiran Media Over the Top tersebut belum dapat membendung pelanggaran hak cipta yang terjadi pada dunia digital. Bahkan, terdapat Media Over the Top juga ikut menayangkan konten-konten yang melanggar hak cipta dari seorang pencipta. Hal ini disebabkan, perkembangan teknologi informasi yang ada justru juga diperuntukkan oleh segelintir orang untuk melangsungkan pelanggaran hak cipta dengan tujuan komersil maupun non-komersil seperti pembajakan film, penayangan hasil pembajakan film secara tidak sah, penggunaan lagu secara tidak sah, dan masih banyak lagi (Tim Lindsey, 2004, p. 163).

Hal tersebut telah jelas meresahkan bagi para pencipta dan menjadi tantangan bagi para pencipta dikarenakan kasus-kasus pelanggaran hak cipta pada Media Over the Top telah sering terjadi. Hal ini membuat suatu pertanyaan besar atas pelindungan hukum pencipta terhadap terjadinya tindakan-tindakan yang tidak sesuai dengan Undang-Undang Republik Indonesia Nomor 28 Tahun 2014 tentang Hak Cipta (UU Hak Cipta) yang dilakukan pada Media Over the Top, terlebih lagi kasus pelanggaran hak cipta sejenis telah kerap terjadi dikarenakan belum terdapatnya suatu upaya penegakkan hukum yang tegas terhadap hal tersebut.

Tindakan hukum yang belum tegas sebagaimana yang dimaksud adalah ketika Kementerian Komunikasi dan Informatika Republik Indonesia yang telah lama berupaya memberantas laman pada beberapa situs yang menayangkan konten-konten yang melanggar hak cipta dengan menutup hak akses terhadap situs tersebut, namun pihak-pihak dibalik laman situs tersebut dengan mudah memindahkan alamat laman ke alamat lain sehingga laman situs tersebut tetap dengan mudah diakses oleh masyarakat luas.

Oleh karena itulah, perlu dilihat juga penegakan hukum diluar ketentuan hak cipta terhadap tindakan pelanggaran hak cipta yang terjadi pada Media Over the Top seperti pada Undang-Undang Nomor 19 Tahun 2016 tentang Informasi dan Transaksi Elektronik (UU ITE), Peraturan Pemerintah Republik Indonesia Nomor 71 Tahun 2019 tentang Penyelenggaraan Sistem dan Transaksi Elektronik (PP PSTE), dan Surat Edaran Menteri Komunikasi dan Informatika Republik Indonesia Nomor 3 Tahun 2016 tentang Penyediaan Layanan Aplikasi dan/atau Konten Melalui Internet (Over the Top) (SE Kominfo Media Over the Top), di mana aturan-aturan tersebut mengatur mengenai konten yang terdapat pada suatu Media Over the Top sebagai suatu sistem elektronik. 
Atas pelanggaran hak cipta pada Media Over the Top tersebut telah jelas menimbulkan suatu kerugian bagi pencipta atas ciptaannya. Terhadap pelanggaran tersebut pencipta tentu dapat mengambil suatu tindakan hukum baik dari rezim hukum hak cipta yang diatur pada UU Hak Cipta maupun rezim hukum teknologi, informasi, dan komunikasi yang diatur dalam UU ITE, PP PSTE, dan SE Kominfo Media Over the Top mengingat pelanggaran hak cipta yang terjadi terdapat pada Media Over the Top yang berbasis sistem elektronik dan internet.

\section{METODE PENELITIAN}

Metode Penelitian yang diterapkan dalam penulisan ini merupakan metode penelitian normatif (normative legal research) yaitu suatu penelitian hukum yang dilakukan dengan cara meneliti bahan pustaka maupun data sekunder, yang mana pendekatan yang digunakan nantinya adalah yuridis normative (statute approach) dengan bersifat deskriptif analitis (Soerjono Soekanto, 2003, p. 13). Maka dalam penulisan ini nantinya, Penulis akan mendasarkan dan menganalisa regulasi-regulasi yang berkaitan dengan pokok permasalahan yaitu pelanggaran hak cipta pada digitalisasi ciptaan di Media Over the Top. Analisa yang akan difokuskan pada penulisan ini adalah terkait dengan perkembangan realitas masyarakat yang menimbulkan suatu permasalahan seperti pelanggaran hak cipta terhadap digitalisasi ciptaan.

Selanjutanya dalam penulisan ini Penulis juga menggunakan data sekunder yang terdiri dari bahan hukum primer yaitu UU Hak Cipta, UU ITE, PP PSTE, dan Peraturan Bersama Menteri Hukum dan Hak Asasi Manusia Republik Indonesia dan Menteri Komunikasi dan Informatika Republik Indonesia Nomor 14 Tahun 2015 Nomor 26 Tahun 2015 tentang Pelaksanaan Penutupan Konten dan/atau Hak Akses Pengguna Pelanggaran Hak Cipta dan/atau Hak Terkait dalam Sistem Elektronik (PBM Penutupan Konten dan Hak Akses), serta bahan hukum sekunder yaitu SE Kominfo Media Over the Top serta literatur hukum dan sumber bacaan hukum lainnya. Terkait pengumpulan data yang penulis terapkan merupakan pengambilan data melalui studi dokumen baik terhadap dokumen kepustakaan seperti buku dan jurnal maupun tugas akhir, serta dokumen yang didapatkan secara daring. Kemudian mengenai cara analisis data yang penulis gunakan adalah dengan melakukan riset terhadap norma hukum yang terdapat dalam peraturan perundang-undangan yang bertujuan untuk menganalisa pokok permasalahan penulisan ini.

\section{HASIL DAN PEMBAHASAN}

\section{Pelindungan Hukum Pencipta terhadap Digitalisasi Ciptaan di Media Over the Top}

Hak Cipta yang merupakan bagian dari pada kekayaan intelektual adalah suatu hak eksklusif yang diberikan terhadap objek pelindungan karya intelektual maupun seni yang memiliki bentuk ekspresi. Ekspresi sendiri merupakan suatu hal yang bercorak tulisan seperti pantun, jurnal, lyric lagu, serta buku, serta suatu hal yang berbentuk gambar seperti lukisan, denah, foto, dan lainnya. Serta suatu hal yang berbentuk video disertai suara seperti film layar lebar, video tarian, video musik, dan lainnya. (Adrian Sutedi, 2010, p. 116). Selain itu juga terdapat pendefinisian hak cipta yang didefinisikan sebagai suatu hak singular yang dimiliki oleh pencipta maupun pihak terkait yang mendapatkan hak terkat melalui suatu perjanjian lisensi terhadap hasil ciptaan dari pada pencipta yang bertujuan untuk menggunakan hak ekonomi dari pada pencipta sesuai dengan UU Hak Cipta. Berdasarkan UU Hak Cipta (OK. Saidin, 2019, p. 199), hak cipta sendiri merupakan:

"Hak cipta adalah hak eksklusif pencipta yang timbul secara otomatis berdasarkan prinsip deklaratif setelah suatu ciptaan diwujudkan dalam bentuk nyata tanpa mengurangi pembatasan sesuai dengan ketentuan peraturan perundang-undangan." 
Pada definisi tersebut dikatakan bahwa hak cipta merupakan suatu hak eksklusif, hak eksklusif pada suatu hak cipta sendiri menurut Pasal 4 UU Hak Cipta terdiri dari hak moral maupun hak ekonomi. Arti dari pada hak moral adalah suatu hak dari pada pencipta untuk dicantumkan namanya apabila terdapat pihak yang menggunakan hak ciptanya dengan seizin pencipta terlebih dahulu (Henry, 2011, p. 14). Terhadap hak moral tersebut, sejatinya tidak dapat dikesampingkan ataupun dihapuskan dari pada pencipta terhadap dalih apapun, meskipun terhadap hak cipta tersebut telah dipindahkan kepada pihak lain, namun pencipta tetap memiliki hak moral terhadap ciptaan yang telah dipindahkannya tersebut (Haris, 2008, p. 17). Kemudian terhadap hak ekonomi merupakan suatu hak guna mengawawi dan mengeksploitasi hasil dari pada suatu hak cipta (Henry, 2011, p. 14). Pelindungan terhadap hak ekonomi tersebut sematamata dikarenakan kekayaan intelektual termasuk ke dalam benda yang memiliki suatu manfaat ekonomi, maka dari itulah pada hak cipta terdapat pelindungan hak ekonomi (Gatot, 2010, p. 45).

Pada Pasal 1 angka 3 UU Hak Cipta sejatinya juga telah ditegaskan mengenai objek pelindungan terhadap hak cipta yang merupakan hasil karya cipta pada aspek ilmu pengetahun, sastra, maupun seni yang dibuat berdasarkan inspirasi, kemampuan, kecekatan, keterampilan, pikiran, imajinasi, ataupun keahilian yang telah diwujudkan dalam suatu bentuk yang nyata. Bentuk kongkrit dari pada objek pelindungan hak cipta juga telah dituliskan pada Pasal 40 ayat (1) UU Hak Cipta antara lain:

a. buku, pamflet, perwajahan karya tulis yang diterbitkan, dan semua hasil karya tulis lainnya;

b. ceramah, kuliah, pidato, dan Ciptaan sejenis lainnya;

c. alat peraga yang dibuat untuk kepentingan pendidikan dan ilmu pengetahuan;

d. lagu dan/atau musik dengan atau tanpa teks;

e. drama, drama musikal, tari, koreografi, pewayangan, dan pantomim;

f. karya seni rupa dalam segala bentuk seperti lukisan, gambar, ukiran, kaligrafi, seni pahat, patung, atau kolase;

g. karya seni terapan;

h. karya arsitektur;

i. peta;

j. karya seni batik atau seni motif lain;

k. karya fotografi;

1. Potret;

m. karya sinematografi;

n. terjemahan, tafsir, saduran, bunga rampai, basis data, adaptasi, aransemen, modifikasi dan karya lain dari hasil transformasi;

o. terjemahan, adaptasi, aransemen, transformasi, atau modifikasi ekspresi budaya tradisional;

p. kompilasi Ciptaan atau data, baik dalam format yang dapat dibaca dengan Program Komputer maupun media lainnya;

q. kompilasi ekspresi budaya tradisional selama kompilasi tersebut merupakan karya yang asli;

r. permainan video; dan

s. Program Komputer.

Pada perkembanganya, terhadap objek-objek hak cipta tersebut, ciptaan tersebut tidak hanya terbatas pada suatu yang konvensional melainkan juga terdapat suatu digitalisasi ciptaan (Putri, 2017, p. 13). Digitalisasi ciptaan sendiri merupakan suatu ciptaan yang dibuat dengan suatu kecanggihan teknologi sehingga membuat objek ciptaan yang terdapat dalam hukum hak cipta juga ikut berkembang mengikuti perkembangan suatu teknologi dalam menghasilkan ciptaan 
tersebut. seperti contohnya adalah film yang mana film saat ini tidak hanya tersedia dalam bentuk compact disc (CD), melainkan film sudah dapat diakses pada internet dengan mudah dengan format mp4 dan yang lainnya. Terhadap digitalisasi ciptaan tersebut, maka penyebaranpenyebaran ciptaan tersebut nantinya juga akan disebarkan pada internet yang salah satunya adalah Media Over the Top. Penyebaran ciptaan melalui Media Over the Top tersebut telah memudahkan masyarakat untuk mendapatkan konten dari pencipta atas ciptaannya.

Media Over the Top sendiri merupakan perwujudan aplikasi yang menyediakan layanan dalam dunia internet digital (Tasya Ramli, 2020, p. 63). Menurut Greene dan Lancaster, Media Over the Top merupakan suatu layanan yang didasarkan pada internet untuk memberikan suatu manfaat bagi pengguna terhadap konten-konten yang terdapat didalamnya (Greene, 2007, p. 12). Di Indonesia, Media Over the Top baru diatur pada SE Kominfo Media Over the Top yang mana pada SE Kominfo Media Over the Top tersebut, Media Over the Top diklasifikasikan menjadi 3 (tiga) jenis antara lain:

a. Layanan berbentuk aplikasi menggunakan media internet pemanfaatan jaringan telekomunikasi menggunakan internet untuk memberikan suatu layanan komunikasi baik dalam bentuk pesan singkat (chatting), panggilan video atau suara, menggunakan media aplikasi untuk bermain game, memberikan suatu layanan transaksi finansial maupun komersial, serta turunannya;

b. Layanan Konten Digital melalui internet merupakan suatu layanan yang menyediakan informasi digital berbentuk tulisan, gambar, suara, musik, video, animasi, dari sebagian dan atau semuanya yang digunakan dengan cara diunduh (download), dialirkan (streaming) dengan menggunakan jasa telekomunikasi menggunakan internet; dan

c. Penyediaan layanan berupa Aplikasi atau konten melalui internet yang selanjutnya disebut dengan Layanan OTT merupakan penyediaan layanan aplikasi dan/atau layanan konten menggunakan internet.

Sehingga dapat dilihat bahwa Media Over the Top merupakan suatu media yang menyediakan layanan aplikasi seperti chatting, voice call, video call, dan lainnya serta penyediaan konten. Istilah Media Over the Top sendiri mungkin masih terdengar asing di masyarakat, namun senyatanya hampir seluruh masyarakat di dunia telah menggunakan Media Over the Top dalam kehidupan kesehariannya. Beberapa contoh Media Over the Top adalah Facebook, Instagram, Netflix, BCA Mobile, Gojek, Line, WhatsApp, dan lainnya.

Melalui Media Over the Top tersebut, setiap orang hampir mengakses maupun mengunggah suatu karya cipta pada Media Over the Top yang diinginkannya. Hal ini menunjukkan bahwa terhadap ciptaan yang awalnya berbentuk konvensional telah berkembang menjadi digitalisasi ciptaan. Dalam Media Over the Top tersebut, setiap orang dapat dengan mudah dan secara bebas mengakses data melalui google maupun browser-browser lainnya. Salah satu akses yang sering digunakan oleh masyarakat adalah menggunggah suatu karya cipta maupun mengakses untuk melihatnya. Setiap orang dapat secara bebas menggunggah suatu karya cipta maupun mengakses karya cipta tersebut yang mana nantinya dapat berpotensi menimbulkan suatu tindakan yang melanggar ketentuan pada UU Hak Cipta. Perbuatan yang melanggar ketentuan UU Hak Cipta atau dapat dikatakan sebagai pelanggaran hak cipta terhadap digitalisasi ciptaan yang kerap dilakukan saat ini adalah seperti pembajakan film, pengunduhan secara tidak sah, penayangan ulang secara tidak sah, dan lain sebagainya. Pelanggaran-pelanggaran tersebut terjadi dikarenakan aturan mengenai hukum hak cipta yang diakomodir pada UU Hak Cipta saat ini masih mengalami beberapa permasalahan dalam memberikan suatu pelindungan hukum yang maksimal terhadap digitalisasi ciptaan (Budi, 2009 , p. 53). Aturan yang belum maksimal ini disebabkan karena pengguna internet maupun Media Over the Top masih dapat dengan mudah mengunduh, menyunting, bahkan melakukan publikasi ulang suatu konten. Terkait batasan pengguna internet agar tidak melakukan suatu 
pelanggaran hak cipta adalah ketika pengguna internet tersebut tidak menggunakan konten ciptaan tersebut untuk kepentingan komersil dan dalam penggunaannya, pengguna internet harus mencantumkan nama pencipta pada konten tersebut sebagai perwujudan hak moral dari pencipta atas ciptaannya yang terdapat pada internet.

Pengaturan UU Hak Cipta yang berlum maksimal dalam mengatur digitalisasi ciptaan serta terdapatnya ciptaan pada internet tersebut membuat masyarakat maupun aparat penegak hukum harus merujuk kepada ketentuan-ketentuan lainnya diluar dari pada UU Hak Cipta seperti pada UU ITE, PP PSTE, dan SE Kominfo Media Over the Top yang mengatur Media Over the Top yang didasarkan pada sistem elektronik sebagai wadah penyebarluasan digitalisasi ciptaan tersebut. Pada Pasal 3 UU ITE telah ditegaskan terhadap eksploitasi dari pada suatu sistem elektronik yang harus berlandaskan terhadap kepastian hukum, manfaat, kehati-hatian, iktikad baik dan kebebasan dalam digunakannya teknologi. Sehingga sudah terlihat jelas pada UU ITE telah diakomodir mengenai suatu sistem elektronik yang berkewajiban untuk tidak melanggar suatu ketentuan hukum lainnya yang salah satunya adalah UU Hak Cipta. Kemudian Pasal 25 UU ITE juga telah mengamanatkan terhadap suatu informasi maupun dokumen elektronik pada situs internet sejatinya dilindungi sebagai hak kekayaan intelektual sesuai dengan masing-masing rezim kekayaan intelektual tersebut. Kemudian dalam Pasal 3 ayat (1) PP PSTE juga diatur mengenai prinsip penggunaan sistem elektronik yang harus secara cakap serta aman dan bertanggungjawab dalam pengoperasiannya sesuai dengan sebagaimana mestinya dan Pasal 5 ayat (1) PP PSTE juga telah menyatakan mengenai sistem elektornik yang tidak diperkenankan untuk memuat informasi maupun dokumen elektronik dengan bertentangan dengan ketentuan peraturan perundang-undangan.

Hal tersebut sejatinya telah menggambarkan bahwa dengan fenomena digitalisasi ciptaan tersebut sangat jelas berpengaruh terhadap model pengaturan hukum terkhususnya hak cipta pada Media Over the Top yang berbasis sistem elektronik. Penerapan UU Hak Cipta saat ini pada faktanya masih memiliki kekurangan. Beberapa kekurangan tersebut disebabkan karena terbatasinya yurisdiksi yang bergantung terhadap hal-hal yang bersifat formal (Sudikno Mertokusumo, 2000, p. 87). Kelemahan dari UU Hak Cipta sendiri juga disebabkan kompleksitasnya dari objek yang diatur pada UU Hak Cipta itu sendiri yaitu ciptaan yang mana pada konteks ini adalah digitalisasi ciptaan (Riswadi, 2009, p. 56). Hal ini telah selaras juga dengan teori Lex Informatica yang merupakan suatu asas, kebiasaan, serta norma dalam mengatur ruang internet dalm tumbuh dan berkembang (Ahmad M. Ramli, 2006, p. 21). Sehingga, hal ini telah menggambarkan mengenai kompleksitas pengaturan UU Hak Cipta yang timbul dikarenakan digitalisasi ciptaan pada internet sendiri terbagi menjadi 2 (dua) yaitu yang pertama adalah hak cipta merupakan suatu buatan karya yang memiliki bentuk informasi, program, karangan dan bentuk lainnya yang serupa dan yang kedua hak cipta merupakan alamat dari pada website maupun alamat email dari masyarakat yang menggunakan jasa internet. (Sitompul, 2004, p. 29).

Maka dari itu meskipun Pasal 54, Pasal 55, dan Pasal 56 UU Hak Cipta telah mengakomodir terhadap suatu ciptaan pada internet atau dapat dikatakan sebagai digitalisasi ciptaan, sejatinya ketentuan tersebut belum dapat memberikan suatu pelindungan hukum hak cipta yang maksimal terhadap pencipta atas ciptaannya yang terdapat pada internet. Hal ini dikarenakan ketentuan pada UU Hak Cipta hanya mengatur mengenai pengawasan maupun tindakan hukum yang dapat dilakukan oleh pencipta jika terdapatnya pelanggaran, yang mana hal tersebut belum dapat menjamin secara menyeluruh dan komperhensif atas hak cipta seseorang yang terdapat pada internet, terlebih lagi masih kurangnya partisipasi pemerintah maupun masyarakat terhadap ciptaan yang terdapat pada internet. Dengan demikian, guna menjamin pelindungan hukum hak cipta terhadap digitalisasi ciptaan yang ada saat ini diperlukan suatu penggantian UU Hak Cipta untuk dapat mencerminkan realitas masyarakat, 
di mana konflik-konflik pada masyarakat atas pelanggaran hak cipta terhadap suatu digitalisasi ciptaan dapat diselesaikan secara memuaskan oleh UU Hak Cipta dengan diberikannya struktur yuridis yang membuat UU Hak Cipta jelas mengatur dan menyelasikan pelanggaran hak cipta tersebut (Satjipto, 2012, p. 140).

\section{Tindakan Hukum Pencipta atas Pelanggaran Hak Cipta di Media Over the Top}

Terhadap pelanggaran hak cipta yang kerap terjadi di Media Over the Top sebagaimana yang diuraikan sebelumnya tentunya dapat dilakukan tindakan hukum dari pencipta ataupun pemegang hak terkait. Pencipta ataupun pemegang hak terkait sejatinya dapat melakukan suatu tindakan hukum sebagaimana yang telah diakomodir pada UU Hak Cipta sebagai bentuk pencegahan terhadap kemungkinan pelanggaran hak cipta. Meskipun UU Hak Cipta telah memberikan pencegahan agar tidak jadinya pelanggaran hak cipta, namun tidak menutup kemungkinan pelanggaran tersebut tetap dapat terjadi. Atas terjadinya pelanggaran hak cipta tersebut, Pasal 95 UU Hak Cipta telah menyatakan sebagai berikut:

(1) Penyelesaian sengketa Hak Cipta dapat dilakukan melalui alternatif penyelesaian sengketa, arbitrase, atau pengadilan.

(2) Pengadilan yang berwenang sebagaimana dimaksud ayat (1) adalah Pengadilan Niaga.

(3) Pengadilan lainnya selain Pengadilan Niaga sebagaimana dimaksud ayat (2) tidak berwenang menangani penyelesaian sengketa Hak Cipta.

(4) Selain pelanggaran Hak Cipta dan/atau Hak Terkait dalam bentuk Pembajakan, sepanjang para pihak yang bersengketa diketahui keberadaannya dan/atau berada di wilayah Negara Kesatuan Republik Indonesia harus menempuh terlebih dahulu penyelesaian sengketa melalui mediasi sebelum melakukan tuntutan pidana."

Ketentuan diatas telah menunjukan bahwa dalam mengambil tindakan hukum dalam mengatasi pelanggaran terhadap UU Hak Cipta, pencipta maupun pemegang hak terkait dimungkinkan untuk menempuh suatu penyelesaian perkara diluar dari pada pengadilan atau dikenal sebagai jalur non litigasi. Jalur non litigasi memang senyatanya merupakan langkah yang efektif dalam menyelesaikan suatu perkara, dikarenakan penyelesaian perkara bisnis yang meluputi kekayaan intelektual baru menempuh jalu pengadilan atau litigasi ketika jalur non litigasi tersebut gagal dilakukan. Hal ini dikarenakan jalur pengadilan atau litigasi merupakan upaya terakhir atau yang biasa dikenal dengan ultimum remidium (Frans, 2013, p. 1-2).

Penyelesaian secara non litigasi yang mungkin untuk dilakukan oleh pencipta ataupun pemegang hak terkait tersebut antara lain yang pertama adalah mediasi. Mediasi sendiri merupakan suatu penyelesaian non litigasi yang terdapat pihak ketiga didalamnya, yang mana pihak ketiga tersebut merupakan mediator yang independen guna membantu pihak yang bersengketa untuk mencapai titik temu terhadap permasalahannya (Joni, 2000, p. 67). Kemudian yang kedua adalah negosiasi yang merupakan jalur non litigasi guna mengatasi permasalahan pihak yang bersengketa melalui suatu metode berembuk untuk mencapai titik temu atas sengketa yang terjadi (Faudy, 2003, p. 42). Selanjutnya yang terakhir adalah konsiliasi yang merupakan metode yang hampir sama dengan mediasi dengan melibatkan pihak lain yang disebut sebagai konsiliator, namun titik temu pada proses ini diperoleh oleh pihak yang bersengketa dan bukan merupakan keputusan konsiliator, dikarenakan konsiliator hanya bertugas mengatur mengenai waktu dan tempat dari proses konsiliasi dilakukan dan juga bertugas untuk mengarahkan subjek pembicaraan (Faudy, 2003, p. 14).

Selain ketiga cara non litigasi tersebut, dalam mengambil suatu tindakan hukum, pencipta ataupun pemegang hak terkait juga dapat menempuh jalur aduan kepada. Direktorat Jenderal Kekayaan Intelektual sebagaiaman yang diatur dalam PPBM Penutupan Konten dan Hak Akses. Melalui aturan PBM Penutupan Konten dan Hak Akses tersebut, pencipta nantinya 
dapat membuat laporan jika memang terdapat pelanggaran hak cipta terhadap ciptaannya pada suatu sistem elektronik yang juga mencakup Media Over the Top. Atas laporan yang diajukan, Direktorat Jenderal Kekayaan Intelektual sebagi pihak yang menerima laporan tersebut nantinya akan melakukan verifikasi dan jika memang nantinya terdapat pelanggaran pada sistem elektronik yang dimaksud, Direktorat Jenderal Kekayaan Intelektual akan mengajukan rekomendasi kepada Direktorat Jenderal Aplikasi Informatika guna dilakukannya penutupan terhadap konten maupun hak akses terhadap sistem elektronik dimaksud melalui penetapan pengadilan sesuai dengan yurisdiksi pengadilan negeri terkait. Aturan PBM Penutupan Konten dan Hak Akses ini merupakan salah satu perwujudan dari adanya digitalisasi ciptaan dan sebagai bentuk antisipasi kerugian yang semakin besar jika terdapatnya pelanggaran hak cipta pada Media Over the Top yang berbasis sistem elektronik.

Jika memang sejatinya kasus tersebut tidak dapat diselesaikan dengan cara non litigasi, pencipta ataupun pemegang hak terkait dapat menyelesaikan sengketa tersebut dengan cara litigasi baik menempuh jalur pidana maupun jalur perdata. Terhadap jalur pidana, sesuai dengan amanat UU Hak Cipta yang terdapat pada Pasal 120 UU Hak Cipta yang berbunyi mengenai tindak pidana hak cipta yang bersifat sebagai delik aduan, maka dari itu terdapat kewajiban untuk menempuh jalur non litigasi terlebih dahulu berupa mediasi sebagaimana yang dimaksud pada Pasal 95 ayat (4) UU Hak Cipta, kecuali terhadap tindakan pelanggaran hak cipta yang berupa pembajakan. Mediasi yang dilakukan pada penyelesaian sengketa hak cipta adalah mediasi penal yang dilandaskan terhadap suatu perbuatan pidana dengan mengutamakan pemberian sejumlah uang atas pelanggaran hak cipta dengan pemberian uang yang sebanding dengan karya cipta dari pada pencipta. Hal tersebut sejatinya dapat membuat pelaku tindak pidana untuk sadar terhadap perbuatannya dan meresahkan pelaku untuk tidak mengulangi lagi perbuatannya (Renni, 2018, p. 2). Kemudian mengenai ganti rugi jika menempuh jalur pidana, pencipta ataupun pemegang hak terkait tidak perlu merasa khawatir mengenai ganti kerugian, dikarenakan penyelesaian sengketa melalui proses pidana tersebut nantinya tetap dapat memberikan ganti kerugian. Hal ini disebabkan dalam UU Hak Cipta telah dimungkinkan bagi Hakim yang mengadili perkara untuk memberikan tuntutan pidana sesuai dengan rumusan delik disertai dengan ganti rugi yang harus dibayarkan kepada pencipta ataupun pemegang hak terkait pada amar putusannya (Ahmad M. Ramli, 2018, p. 48-49).

Selain menempuh jalur pidana, tentunya terdapat pilihan lain bagi pencipta ataupun pemegang hak terkait dalam menyelesaikan sengketa pelanggaran hak cipta melalui ranah hukum perdata. Pada UU Hak Cipta telah diakomodir tindakan hukum yang dapat dilakukan pencipta ataupun pemegang hak terkait melalui jalur perdata pada Pasal 96 UU Hak Cipta yang berbunyi:

"(1) Pencipta, pemegang Hak Cipta dan/atau pemegang Hak Terkait atau ahli warisnya yang mengalami kerugian hak ekonomi berhak memperoleh Ganti Rugi.

(2) Ganti Rugi sebagaimana dimaksud pada ayat (1) diberikan dan dicantumkan sekaligus dalam amar putusan pengadilan tentang perkara tindak pidana Hak Cipta dan/atau Hak Terkait.

(3) Pembayaran Ganti Rugi kepada Pencipta, Pemegang Hak Cipta dan/atau pemilik

Hak Terkait dibayarkan paling lama 6 (enam) bulan setelah putusan pengadilan yang berkekuatan hukum tetap."

Ketentuan ini sejatinya telah memberikan pelindungan hak bagi pencipta ataupun pemegang hak terkait jika mengalami kerugian atas terlanggarnya hak ekonomi yang dimilikinya dengan melayangkan gugatan untuk memperoleh ganti kerugian. Gugatan yang dilayangkan tersebut sesuai dengan Pasal 96 UU Hak Cipta ditujukan kepada Pengadilan Niaga sebagai pengadilan yang memiliki kewenangan untuk mengadili sengketa pelanggaran hak cipta. Dalam mengajukan gugatan, pencipta ataupun pemegang hak terkait sebagai penggugat memiliki 
beban pembuktian untuk membuktikan terhadap dalil-dalilnya pada muka persidangan, hal ini telah selaras dengan asas actori incumbit probation yang mengungkapkan siapa yang menggugat dialah yang harus membuktikan dalilnya (Soeparman, 2013, p. 23). Jika penggugat tidak dapat membuktikan mengenai dalil gugatannya, maka gugatan tersebut berisiko dinyatakan ditolak untuk seluruhnya oleh Majelis Hakim nantinya (Sudikno Mertokusumo, 1984, p. 193).

Setelah mengajukan gugatan tersebut, pencipta ataupun pemegang hak terkait nantinya akan menempuh proses pembuktian dalam persidangan yang mana pembuktian sendiri merupakan suatu proses persidangan yang bertujuan untuk mendapatkan suatu kepastian bagi hakim terhadap (Ansorie, 1990, p. 185):

a. Mengenai pertanyaan apakah peristiwa atau perbuatan tertentu sungguh pernah terjadi; dan

b. Mengenai pertanyan mengapa peristiwa ini terjadi. Oleh karena itu, dapat disimpulkan bahwa pembuktian terdiri dari menunjukan peristiwa yang dapat diterima oleh panca indera, memberikan keterangan tentang peristiwa yang telah diterima tersebut, dan menggunakan suatu pemikiran yang logis.

Untuk melalui proses pembuktian tersebut, pencipta ataupun pemegang hak terkait dapat mengajukan alat bukti sebagaimana yang diatur dalam Pasal 164 Herzien Inlandsch Reglement (HIR) yaitu:

1) Surat;

2) Saksi;

3) Pengakuan;

4) Persangkaan; dan

5) Sumpah.

Seiring perkembanganya, saat ini juga telah diakomodir alat bukti lainnya diluar dari yang telah disebutkan di atas yaitu alat bukti elektronik. Melalui UU ITE, maka informasi maupun dokumen elektronik termasuk alat bukti yang sah dipersidangan (Panggabean, 2012, p. 281). Sehingga, dalam kasus pelanggaran hak cipta yang terjadi pada Media Over the Top, pencipta ataupun pemegang hak terkait dapat mengajukan alat bukti elektronik guna mendukung dan membuktikan dalil-dalil yang terdapat dalam gugatannya.

Dengan demikian terhadap tindakan yang bertentangan dengan UU Hak Cipta yang terjadi di Media Over the Top, pencipta ataupun pemegang hak terkait dapat menempuh tindakan-tindakan hukum sebagaimana yang telah diakomodir dalam PBM Penutupan Konten dan Akses serta UU Hak Cipta guna memperoleh suatu pelindungan hukum dan penggantian kerugian yang diderita oleh pencipta ataupun pemegang hak terkait.

\section{KESIMPULAN DAN SARAN}

\section{Kesimpulan}

1. Bahwa UU Hak Cipta belum mengakomodir dengan komperhensif terhadap Hak Cipta yang terdapat dalam internet terlebih lagi terhadap digitalisasi ciptaan yang terdapat pada Media Over the Top yang dilandaskan pada sistem elektronik. Meskipun pada Pasal 54, Pasal 55, dan Pasal 56 UU Hak Cipta telah mengakomodir terhadap Hak Cipta yang terdapat di internet, namun dalam melihat pelindungan UU Hak Cipta pada internet tersebut perlu dilihat lagi pada ketentuan UU ITE, PP PSTE, maupun SE Kominfo Media Over the Top. Maka dari itu, UU Hak Cipta yang ada saat ini perlu direvisi agar dapat mencakup secara komperhensif terhadap digitalisasi ciptaan.

2. Bahwa terhadap pelanggaran hak cipta yang terjadi di Media Over the Top, pencipta ataupun pemegang hak terkait dapat menempuh tindakan hukum non litigasi berupa 
mediasi, negosiasi, konsiliasi, serta upaya pengajuan laporan kepada Direktorat Jenderal Kekayaan Intelektual sesuai dengan PBM Penutupan Konten dan Hak Akses serta upaya hukum litigasi melalui jalur pidana ataupun jalur perdata dengan diajukannya gugatan ganti rugi ke pengadilan niaga.

\section{Saran}

1. Indonesia seharusnya saat ini telah melakukan revisi terhadap UU Hak Cipta dengan mencakup secara komperhensif mengenai pelindungan hukum Hak Cipta pada media digital, mengingat telah banyaknya Hak Cipta yang dipublikasikan secara digital, sehingga diperlukan pelindungan hukum oleh pemerintah terhadap Ciptaan-Ciptaan yang dipublikasikan secara digital melalui UU Hak Cipta.

2. Pencipta ataupun pemegang hak terkait dalam menempuh tindakan hukum terhadap pelanggaran hak cipta yang dideritanya harus mengutamakan jalur non litigasi terlebih dahulu dan jika pada akhirnya tidak dapat diselesaikan baru menempuh jalur litigasi yang merupakan ultimum rimidium dengan memerhatikan jalur sesuai dengan keinginan yang pencipta ataupun pemegang hak terkait inginkan.

\section{DAFTAR PUSTAKA}

\section{Buku}

Adrian Sutedi, (2010), Hak Atas Kekayaan Intelektual, Jakarta: Sinar Grafika.

Ahmad M. Ramli, (2006), Cyber Law dan Haki dalam Sistem Hukum Indonesia, Bandung: Armico.

Ahmad M. Ramli, (2018), Hak Cipta Disrupsi Digital Ekonomi Kreatif, Bandung: Alumni.

Ansorie Sabuan, dkk., (1990), Hukum Acara Pidana, Bandung: Angkasa.

Asril Sitompul, (2004), Hukum Internet, Bandung: Citra Aditya Bakti.

Budi Agus Riswandi, (2009), Hak Cipta di Internet Aspek Hukum dan Permasalahannya di Indonesia, Yogyakarta: FH UII Press.

Frans Hendra Winata, (2012), Hukum Penyelesaian Sengketa: Arbitrase Nasional dan Internasional, Jakarta: Sinar Grafika.

Gatot Supramono, (2010), Hak Cipta dan Aspek-Aspek Hukumnya, Jakarta: Rineka Cipta.

Haris Munandar dan Sally Sitanggang, (2008), Mengenal HAKI (Hak Kekayaan Intelektual), Jakarta: Erlangga.

Henry Soelistyo, (2011), Hak Cipta tanpa Hak Moral, Jakarta: RajaGrafindo Persada.

H. P. Panggabean, (2012), Hukum Pembuktian Teori Praktik dan Yurisprudensi Indonesia, Bandung: Alumni.

Joni Emirzon, (2000), Alternatif Penyelesaian Sengketa di Luar Pengadilan (Negosiasi, Mediasi, Konsoliasi, dan Arbitrase), Jakarta: Gramedia Pustaka Utama.

M. Fikri, 2018, Sejarah Media: Transformasi, Pemanfaatan, dan Tantangan, Malang: UB Press.

Munir Faudy, (2000) Arbitrase Nasional: Alternatif Penyelesaian Sengketa Bisnis, Bandung: Citra Aditya Bakti.

OK. Saidin, (2019), Aspek Hukum Hak Kekayaan Intelektual, Depok: RajaGrafindo Persada.

Riswandi dan Budi Agus, (2009), Hak Cipta di Internet: Aspek Hukum dan Permasalahannya di Indonesia, Yogyakarta: FH UII Press.

Satjipto Raharjo, (2012), Sosiologi Hukum: Perkembangan Metode dan Pilihan Hukum, Jakarta: Genta Pers.

Soerjono Soekanto, (2003), Sosiologi Suatu Pengantar, Jakarta: Raja Grando.

Straubhaar, Joseph D. \& Robert LaRose, (2012), Media Now (Understanding Media, Culture, and Technology), Boston: Wadsworth. 
Sudikno Mertokusumo, (1984), Bunga Rampai Ilmu Hukum, Yogyakarta: Liberty.

Sudikno Mertokusumo, (2000), Penemuan Hukum Sebuah Pengantar, Yogyakarta: Liberty.

Tim Lindsey, dkk., (2004), Hak Kekayaan Intelektual Suatu Pengantar, Bandung: Alumni.

\section{Tesis dan Jurnal}

Borja dan Dieringer, (2016), Streaming or Stealing? The Complementary Features between Music Streaming and Music Piracy, Journal of Retailing and Costumer Services.

Darmawan Napitupulu, (2017), Kajian Peran Cyber Law dalam Memperkuat Keamanan Sistem Informasi Nasional, Jurnal Media Neliti.

Greene, Wedge dan Lancaster, Barbara, (2007), Over The Top Services, Pipeline Magazine, London: Pipeline Publishing.

Putri Yan Dwi Akasih, (2017), Perlindungan Hak Cipta di Internet Melalui Creative Commons, Business Law Review, Volume 2.

Renni Sartika dan Marcus Priyo Gunarto, (2018), Penyelesaian Sengketa Pelanggaran Hak Cipta yang Berunsur Tindak Pidana Melalui Proses Mediasi Penal, Yogyakarta: Tesis Universitas Gadjah Mada.

Tasya Safiranita Ramli, dkk., (2019), Commercialization of Copyright Content Through Digital Platforms in Indonesia, Progressive Law Review, Volume 1 Nomor 1.

Tasya Safiranita Ramli, dkk., (2020), Over-The-Top Media in Digital Economy and Society 5.0, Journal of Telecommunications and the Digital Information.

\section{Peraturan Perundang-Undangan}

Undang-Undang Republik Indonesia Nomor 28 Tahun 2014 tentang Hak Cipta.

Undang-Undang Nomor 19 Tahun 2016 tentang Informasi dan Transaksi Elektronik.

Peraturan Bersama Menteri Hukum dan Hak Asasi Manusia Republik Indonesia dan Menteri Komunikasi dan Informatika Republik Indonesia Nomor 14 Tahun 2015 Nomor 26 Tahun 2015 tentang Pelaksanaan Penutupan Konten dan/atau Hak Akses Pengguna Pelanggaran Hak Cipta dan/atau Hak Terkait dalam Sistem Elektronik.

Peraturan Pemerintah Republik Indonesia Nomor 71 Tahun 2019 tentang Penyelenggaran Sistem dan Transaksi Elektronik

Surat Edaran Menteri Komunikasi dan Informatika Republik Indonesia Nomor 3 Tahun 2016 tentang Penyediaan Layanan Aplikasi dan/atau Konten Melalui Internet (Over The Top).

Herzien Inlandsch Reglement (HIR). 